\title{
Critical elements in teacher collaboration to generate change when bringing an English language focus to science teaching
}

\author{
New Zealand Journal of Teachers' Work, Volume 16, Issue 1 \& 2, 48-63, 2019
}

\author{
SUSAN GRAY \\ GILLIAN WARD \\ The University of Auckland \\ Auckland, New Zealand
}

\begin{abstract}
Peer learning offers powerful spaces for teachers to reconsider beliefs and change practice. Although productive teacher collaborations have been identified, there are few descriptive accounts explaining the detail of these collaborations and specifying conditions that enabled teachers to learn from each other. This article explores the ways in which two secondary school science teachers used the framework of an action research project to take a language focus in the teaching of science. This joint work involving devising, implementing and evaluating a work plan, enabled them to challenge their beliefs and practices. Insights into requisite conditions and the dilemmas experienced for any collaboration leading to teacher change in beliefs and practices when bringing a specific language focus to their science teaching are explored.
\end{abstract}

\section{INTRODUCTION}

Inquiry that is shared enables teachers' experience to be used as a means to explore the difficulties, questions and interests that arise through their teaching. Too often, however, teachers' "knots of practice" remain unexplored and unanswered in the intensification of school life (Hargreaves, 2000). Alternatively, the collaboration that is organised does not meet particular teacher and student needs (Levine \& Marcus, 2010). If there is to be meaningful teacher learning then teachers need to have the necessary conditions to re-examine beliefs and practices.

Curriculum initiatives are prime opportunities for teacher learning. One reform context in New Zealand is the requirement for all teachers to teach the language of their subject and create opportunities for students to use that language. The New Zealand Curriculum (NZC) (Ministry of Education, 2007) outlines clearly the place of a language focus in subject teaching. Specifically, teachers' attention is drawn to the need to focus on "the specialist vocabulary associated with that area:

- how to read and understand its texts;

- how to communicate knowledge and ideas in appropriate ways; 
- how to listen and read critically, assessing the value of what they hear and read" (MOE, 2007, p. 16).

While the curriculum suggests all learners will benefit from such an explicit focus on subject-area language, there is an urgency for new learners of English. The number of English Language Learners (ELLs) in the school system has increased exponentially since changes to New Zealand immigration policy in 1987. All teachers have had to grapple with how to teach their subject area to an increasingly linguistically diverse population. Given this issue and the explicit statements within the NZC, an exploration of the ways in which teachers collaborate to achieve these goals is warranted.

The literature regarding professional development that supports the science teaching of English language learners is still emerging (Lee \& Buxton, 2013). While collaborations have been identified to support teacher professional learning (Loughland \& Nguyen, 2016), there is little research in which the specific nature of these collaborations, particularly in the secondary sector, have been described. The study outlined in this article focuses on the ways in which two secondary school science teachers engaged in a shared inquiry by collaborating within an action research project. In doing so these teachers were able to reexamine their beliefs and practices about teaching science with a language focus.

\section{THE FRAMEWORK: KEY ELEMENTS OF INTERDEPENDENCE IN TEACHER COLLABORATION}

Meirink, Imants, Meijer, and Verloop (2010) found that teacher professional learning was noticeably facilitated in temporary teams where participation was voluntary and where there was autonomy for teachers to pursue their own topics of interest or concern. The participants in their study, conducted in the Netherlands, were secondary school teachers working in cross-disciplinary teams to implement reforms focusing on self-regulation in senior secondary students. These authors found that teams which had achieved high degrees of interdependency - that is, managed to establish shared goals, shared teaching examples and produced a shared plan - were more satisfied with the collaborative experience than those who worked in teams which had achieved a lower level of interdependence and, for example, did not exchange ideas about their experimentation with ways for shared problem solving.

Meirink et al. (2010) considered different levels of interdependence, from least to most, when examining teacher collegiality (Fig. 1). The results of their study showed that collaboration and teacher learning were closely interconnected. In particular, that learning related to changes in: a) pedagogical beliefs; b) classroom practices; and c) collaborative work relationships with colleagues. In discussing the conditions needed for teacher learning, Meirink et al. (2010) argue that, if teams are to move from just sharing, to joint work, then their leaders and coaches need to stimulate them "to experiment with alternative teaching methods in their practices in such a way that that it contributes to solving a shared problem" (p. 170). In addition to exchanging ideas and experiences with experiments in teaching practice, teachers should also be encouraged to use artefacts, such as lesson plans, that teachers within, and external to, the team can utilise. When all teachers contribute to designing such artefacts the level of 


\begin{tabular}{|c|c|c|}
\hline Level of & Name of the level & Description of the level \\
\hline Least & $\begin{array}{l}\text { Storytelling and } \\
\text { scanning }\end{array}$ & $\begin{array}{l}\text { Relating to brief informal } \\
\text { exchanges where individual issues } \\
\text { with students or class difficulties } \\
\text { were exchanged. }\end{array}$ \\
\hline & Aid and assistance & $\begin{array}{l}\text { Exchanging individual experiences, } \\
\text { critically examining them and giving } \\
\text { feedback reflecting an intermediate } \\
\text { level of interdependence. }\end{array}$ \\
\hline & Sharing & $\begin{array}{l}\text { Exchanging ideas and experiences } \\
\text { and methods which lead to } \\
\text { individual or shared problem } \\
\text { solving and opening up of } \\
\text { classroom life to colleagues. }\end{array}$ \\
\hline Most & Joint work & $\begin{array}{l}\text { Sharing problems and planning - } \\
\text { implying that teachers exchange } \\
\text { experiences, ideas and methods } \\
\text { aimed at developing innovative } \\
\text { teaching practices and develop a } \\
\text { "collective responsibility for the } \\
\text { work of teaching" (p. 164). }\end{array}$ \\
\hline
\end{tabular}

Fig. 1 Levels of interdependence and their description

interdependence increases. Key in this process, they insist, is that teachers need to be given autonomy - in both the process and topic choice.

Arguing that departments in The Netherlands have well established collegial relationships, Meirink et al. (2010) chose not to work with secondary subject departments. This is not always the case in New Zealand where concern has been raised about the lack of systemic opportunities for collaborative work that exist for secondary teachers, even in the same subject areas (Wylie, 2010). This article addresses this gap by exploring an example of collaboration between a pair of secondary science teachers in a New Zealand secondary school.

\section{The research questions}

- What is the nature of collaboration between two experienced New Zealand secondary school science teachers, using a language focus when teaching science?

- Within this collaboration, what are the specific elements or conditions that enabled the two science teachers to learn from one another?

- How do two experienced New Zealand secondary school science teachers use these elements or conditions to make changes to their beliefs and practices when bringing a specific language focus to their science teaching? 


\section{METHODOLOGY}

Action research (Elliot, 1991) was used in the current study. The rationale for using Elliot's framework was that it facilitates not just talk, but also action. In addition, while Meirink et al. (2010) argue for teacher collaboration they did not propose action research as a methodological framework to guide such inquiries promoting interdependence. As such, this study has a different methodological focus.

Using Elliot's (1991) six stages of action research allowed the teachers to frame their own collaborative inquiries. Key to this approach is that the teacher decides on the focus for the inquiry in light of their own concerns or interests in student learning. It was thought that an action research project could create opportunities for interdependence that in turn would lead to teacher learning. In the current study, two science teachers volunteered to collaborate with each other on an action research project, by teaching a sequence of science lessons about plants, which had a language focus.

\section{Context}

The participants in the current study were both graduates of a TESOL programme offered by a large New Zealand university. The purpose of this teacher education programme was to develop teachers' ability to draw on the strengths, and meet the language learning needs, of bilingual and multilingual students in schools within a super-diverse urban city. We were particularly interested in ways teachers were able to continue using this knowledge base once they had successfully completed courses within the programme. We had become concerned to hear graduates lamenting, "we know what to do, it's just we can't do it". These comments alerted us to the discrepancy between graduates' current and desired states of teaching (Higgins, 1996; Kubaniyova, 2009) and the need to better understand the elements or conditions that teachers need for on-going learning. As a consequence, an action research study was set up by a TESOL teacher educator, between pairs of teachers who taught the same subject. The current study, which focused on one of the pairs of teachers who taught science, was part of the larger study.

The pairs used project resources provided by the TESOL teacher educator to plan, teach and evaluate a sequence of language-focused content lessons. The resources consisted of a project manual containing summaries of the key principles and practices covered in their programme of study. This material and its suggested use in teacher planning followed Kaufman and Crandall's (2005) identification of required aspects of teacher knowledge for English language learning in content teaching: 1) knowledge about language; 2) knowledge about language pedagogy; and 3) knowledge about second language acquisition.

\section{Participants}

The participants in the current study were two secondary school science teachers, Mark and Dianne (pseudonyms). They both taught in different schools and had been teaching for less than 10 years. Mark was completing the last course of the TESOL programme while Dianne had graduated 2 years previously. Prior to collaborating on the action research project, Dianne and Mark had met only briefly before, in a language and science workshop. For their action research project, they decided they would work with their Year 11 (aged 15-16) science 
classes. In these "Alternative Science" classes, the students were not studying towards any NCEA ${ }^{1}$ achievement standards but the content of the lessons aligned with Level 6 of the NZC (2007). Dianne and Mark's multicultural classes comprised fifty percent of students who did not have English as their first language. Mark had a class of 18 students and Dianne had a smaller class of just 10 students. While they taught in different schools, both teachers taught in large mid-decile urban schools with a similar socioeconomic background.

\section{Data collection and analysis}

The four-month period of data collection comprised three phases. Phase 1 involved individual semi-structured interviews between the TESOL teacher educator and the teachers (Table 1). The interview questions focused on what they considered enabled or constrained their taking a language focus while teaching science. After the interview the TESOL teacher educator made one classroom observation with each teacher, with field notes being made about the language focus in action.

Table 1 Phase 1 and Phase 3

\begin{tabular}{ll}
\hline Methods of data collection & Data \\
\hline Semi-structured interview with individual teachers. & Interview transcripts \\
Observation by researcher of one lesson for each of & Field notes \\
the participants with the class chosen for the & Classroom transcripts \\
project. & \\
\hline
\end{tabular}

Phase 2 comprised Elliot's six stages of action research (Table 2). A number of methods were used to collect data during Phase 2. These included: crosscurricular focus groups with pairs from the larger study; participants' teacher discussion; document analysis of the completed worksheets and diary entries kept by the teachers throughout the project; teacher lesson observation of the other pair; classroom observation by the TESOL teacher educator and individual reports evaluating the project.

Initially the teachers worked on their action research projects over two full days (stages 1 to 4 ). During these two days the teachers worked together to plan a sequence of lessons and develop resources they would use in their teaching. This was followed by the implementation of a sequence of eight lessons (stage 5). During this stage the TESOL teacher educator gathered data through classroom observation of the lesson sequence implementation (two lessons for each participant) and the teachers within the pair also observed each other. In stage 6 the participant teachers came together with the other non-science teachers for one day to evaluate the lesson sequence with each other. Phase 3 of the research design was a repeat of Phase 1 in which the TESOL teacher educator conducted individual semi-structured interviews and a classroom observation.

After a number of close readings of the complete data set, a visual table (Miles and Huberman, 1994) was drawn up with the qualitative coding of units of

\footnotetext{
${ }^{1}$ National Certificate of Educational Achievement
} 
Table 2 Phase 2: The Collaborative Action Research Project

\begin{tabular}{|c|c|c|c|}
\hline \multicolumn{2}{|c|}{ Stage of the project } & \multirow{2}{*}{$\begin{array}{l}\text { Methods of data } \\
\text { collection }\end{array}$} & \multirow[t]{2}{*}{ Data } \\
\hline $\begin{array}{l}\text { Meirink et } \\
\text { al. (2010) } \\
\text { framework }\end{array}$ & Elliot's (1991) stages & & \\
\hline \multirow{4}{*}{ 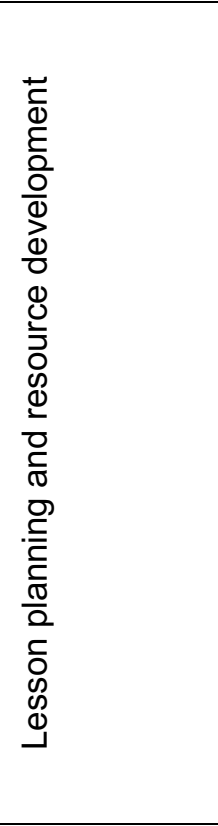 } & $\begin{array}{l}\text { Stage 1: } \\
\text { Teachers identify } \\
\text { and conceptualise } \\
\text { the problem under } \\
\text { investigation }\end{array}$ & $\begin{array}{l}\text { Focus group cross- } \\
\text { curricular and } \\
\text { teaching pairs } \\
\text { discussion }\end{array}$ & $\begin{array}{l}\text { Transcript of } \\
\text { discussions }\end{array}$ \\
\hline & $\begin{array}{l}\text { Stage } 2: \\
\text { Teachers explore } \\
\text { and clarify the } \\
\text { problem }\end{array}$ & $\begin{array}{l}\text { Focus group cross- } \\
\text { curricular and } \\
\text { teaching pairs } \\
\text { discussion }\end{array}$ & $\begin{array}{l}\text { Transcript of } \\
\text { discussions }\end{array}$ \\
\hline & $\begin{array}{l}\text { Stage 3: } \\
\text { Teachers' } \\
\text { reconnaissance }\end{array}$ & $\begin{array}{l}\text { Teaching pair } \\
\text { discussion }\end{array}$ & $\begin{array}{l}\text { Transcript of } \\
\text { discussions }\end{array}$ \\
\hline & $\begin{array}{l}\text { Stage 4: } \\
\text { Teachers' construct } \\
\text { the general plan } \\
\text { and develop the } \\
\text { next action steps }\end{array}$ & $\begin{array}{l}\text { Teaching pair } \\
\text { discussion }\end{array}$ & $\begin{array}{l}\text { Transcript of } \\
\text { discussions }\end{array}$ \\
\hline 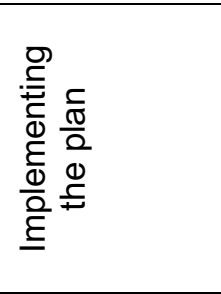 & $\begin{array}{l}\text { Stage 5: } \\
\text { Teachers' teach } \\
\text { the lesson } \\
\text { sequence using } \\
\text { shared principles } \\
\text { and practices }\end{array}$ & $\begin{array}{l}\text { Document analysis } \\
\text { Participant } \\
\text { Observation } \\
\text { Researcher } \\
\text { Observation }\end{array}$ & $\begin{array}{l}\text { Participants' } \\
\text { diaries } \\
\text { Written report } \\
\text { Field notes } \\
\text { Classroom } \\
\text { transcripts }\end{array}$ \\
\hline 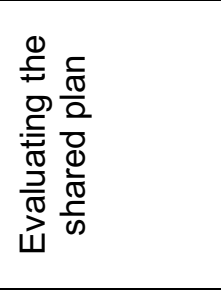 & $\begin{array}{l}\text { Stage 6: } \\
\text { Teachers' evaluate, } \\
\text { report, and decide } \\
\text { on further action }\end{array}$ & $\begin{array}{l}\text { Focus group cross- } \\
\text { curricular and } \\
\text { teaching pairs } \\
\text { discussion } \\
\text { Document analysis } \\
\text { Individual reports }\end{array}$ & $\begin{array}{l}\text { Transcript of } \\
\text { discussions } \\
\text { Written reports }\end{array}$ \\
\hline
\end{tabular}

analysis. From the data set, relevant comments, words, and phrases related to these broad categories were recorded. The analysis proceeded to define, revise and narrow (Bryman, 2012) the changes in the participants' pedagogical beliefs; classroom practices; and, collaborative work practices.

\section{FINDINGS}

Elliot's (1991) stages in an action research project are used to frame the findings for the current study and are described below, under each of the six stages of Elliot's framework. 


\section{Stage 1: Sharing difficulties in implementing an academic language focus in science teaching}

Mark and Dianne agreed that what hindered their ongoing focus on language within their science teaching was insufficient time for planning and a lack of appropriate language-centred science resources. Additionally, Mark felt that his science students' beliefs about what should be covered in science impeded this. In one of his attempts to focus on grammar in a science lesson, drawing students' attention to different parts of speech in a science text, their response was, "This is not English, sir." After completing her TESOL qualification Dianne moved schools and has had difficulty sustaining a language focus in her science teaching as her current science department lacked interest in this aspect of the curriculum. Consequently, they both saw the action research project as a way to reconnect with language teaching. Dianne acknowledged that "It's very easy to get weighed down, frustrated and the longer you are away from [the TESOL programme], the easier it is to drift away" (Phase 1 interview). The interviews revealed beliefs around a language focus in science, dissatisfaction with their current teaching and discouragement over departmental resources. At this first stage of the project they felt a lack of: time; resources; student buy-in; collegial interest; and, external support.

\section{Stage 2: Identifying and categorising student academic language needs}

Dianne and Mark agreed that, although they were teaching different classes in different schools, their students had similar needs. Their students lacked confidence, particularly in their ability to write about the scientific content they were learning. Mark and Dianne also noticed that their students often wrote one-word answers. As a result, the teachers settled on a common language goal for their lesson sequence about plants. The specific goal was writing appropriate sentences about scientific content. This goal linked to the statement in the NZC (2007) regarding "how to communicate knowledge and ideas in appropriate ways" (p. 16). While Mark and Dianne believed their students could achieve these goals, they were yet to find more effective teaching approaches in order to achieve their common goal.

\section{Stage 3: Considering their own principles underpinning their language- focused teaching}

Dianne and Mark discussed the principles of their current teaching practice regarding a language focus in science, drawing on information from the project manual that they had been given. While they worked together and discussed the principles, they realised they had different underpinning principles. Mark's principles included providing comprehensible input through teacher-guided discussion, group and paired activities, individual reading and "having a range of language tasks and vocabulary activities following the practical science activities" (project manual). For Dianne, the key was to "guide students to levels of thinking beyond their current capability" (project manual).

\section{Stage 4: Deciding on shared principles, goal, practices and work plan}

Through discussion with each other, Mark and Dianne then decided which principles would underpin their lesson sequence to meet identified student need. Eventually, they settled on "careful sequencing of the tasks in a way that would help students remember the vocabulary through meaningful opportunities for 
repetition of key concepts" (paired teacher discussion). But in reaching this shared principle the teachers were initially uncertain about the goal, as the following excerpt illustrates:

Dianne: So do we want to get writing in there at all?

Mark: We do, don't we? Do we?

Dianne: All this has got to come to something... Are we going to focus on sequencing written work? Cos we have to do something with the sequencing and repetition. We have to have a goal ... so theoretically that could be our written work. (Paired teacher discussion)

After two planning days they had refined the specific language focus to "mainly description with some explanation" as a final linguistic product. They decided the practical experiment of planting seeds and tending the seedlings would engage and motivate their students. Although both worked on designing the tasks, Dianne -who had more experience in shared design of language-focused science taskstook the lead. Mark was appreciative of her support noting that "Dianne is a whiz with the computer and our resources are taking shape" (Mark diary entry). He was aware that it would have taken him more than twice as long to complete this planning alone.

\section{Stage 5: Implementing the shared plan}

Dianne and Mark appreciated the value of working together to develop carefully crafted interactive activities for student learning. In implementing and evaluating their joint work, the shared plan, Mark and Dianne had to sustain experimentation with the new language tasks for the eight-lesson sequence. Implementation of the plan meant first convincing their students of the value of this language focus in science. Mark had previously been concerned that his students would not be interested in such activities. Mark, who knew the language tasks but was new to implementing them, found that he needed to explain this new approach:

I'm always asking myself now what kind of questions should I ask now that will get them thinking about their own learning. That's often hard to do ...What I found was that having this planning it was more natural in fact because they'd ask me first of all, 'Why are we doing this?' And 'what's the point of doing that? We've never seen this before.' They would force me to justify it. (Written project evaluation)

Dianne, more practiced in implementing language tasks, as were her students in task participation, still found she had to recruit student interest and engagement. Her students had responded in the first lesson, "'Oh this is like English.' [l] sold the whole idea of writing proper sentences rather than writing long paragraphs about each picture. [I] sort of convinced them of this" (Dianne diary entry). By the final lesson, writing sentences was an expected and predictable dimension in science. 
New to sustained activity implementation, Mark found different aspects of their shared plan challenging. For example, he found familiarising the students with the procedures for participating in the activities took time and consequently found it difficult to complete the number of activities planned for each lesson.

Often, he found he had given insufficient whole-class teacher explanation before expecting students to perform tasks. He dealt with students' uncertainty by working with small groups or individuals and focused on questioning and negotiating to help students complete the task but found this took time.

Because of the time it took to construct sentences with the students, Mark found it difficult to complete all the activities that he and Dianne had planned for the lessons about plants. However, he realised that joint construction was important. His approach led him to write: "more teacher-student discussion, modelling, and joint construction would be more useful than additional tasks" (Mark diary entry). After this lesson, Mark also recorded, "So far, I'm not sure that we are heading towards our goal of improving students' written descriptions. But there have been other good [unexpected] outcomes ...from doing this intensive planning ... but these are not what I had envisioned. ... one is that the students seem to be quite a lot more attentive to detail ... more interested in learning new words about plants, soil, etc."

Dianne was more familiar with the science topic, as was her class in participating in the various language activities, so therefore, all planned activities were completed on schedule. In addition to teacher-talk and joint construction, she would often design an additional activity to remedy a gap that she had noticed in moving students from talking (for example describing plant parts) to writing about them. In particular, she was able to institute class discussion where individuals and pairs of students could report back after completing an activity. She was able to use hers and Mark's shared goal to push her students in both oral and written responses far beyond their usual one- or two-word answers.

\section{Stage 6: Evaluating the shared plan and reflecting on their collaboration}

Both teachers witnessed the benefits such a sustained language focus had on student engagement. During the project, their sustained experimentation for the lesson sequence convinced them of the need for a consistent focus on academic language in science.

Mark admitted that in the early stages of his study he had not been confident enough to use many of the language tasks and reflected that he has changed his teaching style:

Before it was all chalk and talk, now a lot more task-based, more interactive, more focused, before it was very loose; there was no framework to tie it together. l'd sort of use it here and there and not really know what to do with it. (Paired teacher discussion)

For Dianne the key learning had come from the consistent implementation of a language focus over the eight lessons. As she explained:

This sort of planning wasn't new to me but to actually force myself to do it for eight lessons in a row ... [there was pressure and] ... the kids have seen all those activities 
during the year but just never consistently. (Paired teacher discussion)

Another revelation for Dianne was what had seemed complicated before now became easier and simplified:

That incorporating language into the curriculum is very simple when one focus is taken and followed through. ... by keeping focused on a simple goal... "description", simplified all the variables and the complexity. (Cross-curricular focus group)

Finally, both reflected that the joint work of planning, implementing and evaluating a lesson sequence was what had helped them sustain momentum. Mark appreciated finally having a language-focused science colleague with whom he could share the "nitty-gritty details of lesson planning". For Dianne it was the affective support of her colleague that gave her renewed energy. She stated:

Having that support ... to keep going because otherwise you know you just get tired, but then there'd be an email and away you'd go again. You're being part of something greater than just yourself. (Phase 3 interview)

In reflecting on the collaboration, Mark, who had not worked with a specialist in science before, realised that, even though those conversations about a language focus had been helpful, he was still not confident enough to bring about changes in classroom practice on his own and wanted further external support. On the other hand, Dianne, now confident in a language-focused approach, was ready to guide and learn with others.

\section{DISCUSSION}

There has been little research in which the specific nature of teacher collaborations, particularly in the secondary sector, have been described. This current study fills this gap by using collaborative action research (Elliot, 1991) and Meirink et al.'s (2010) research to provide the framework to detail Mark and Dianne's joint work and examine the nature of their collaboration.

This study adds weight to Meirink et al.'s (2010) research by demonstrating how their framework is applicable to teachers working in the same subject area. While Garet, Porter, Desimone, Birman, and Yoon (2001) suggest that teacher professional development is best arranged within a teacher's own school or department, Lee and Buxton (2013) call for collaboration between science teachers and teachers from other curriculum areas. The current arrangement across schools, sharing and working on a joint project, provided the necessary impetus for Mark and Dianne to develop the series of lessons, despite the perceived lack of support from their respective departments. Through the teachers' collaborative process, they engaged in professional learning with each other and with other non-science teachers in which they re-examined beliefs and classroom practices when bringing a language focus to their science teaching, 
thus taking full advantage of the opportunities to integrate content and language learning (Lee \& Buxton, 2013).

\section{Nature of the collaboration between Dianne and Mark}

An essential preliminary stage for any collaborative action research is an exploration of current difficulties experienced or dilemmas that are intriguing before identifying a shared goal. Often teacher inquiry cycles (MOE, 2007) begin with identifying students' needs or difficulties rather than acknowledging that teachers experience their own. In this opportunity to share their difficulties, Mark and Dianne understood more deeply the constraints of their current situations, in particular the lack of time and resources (human and material) to plan for an academic language focus. That these difficulties were shared and understood immediately addressed the isolation that so many teachers experience in their work (DiPardo \& Potter, 2003; Hargreaves, 2000).

A number of stages guided the teachers in their thinking before identification of their shared goal. Through this action research project, teachers were engaged in active learning (Garet et al., 2001) by being involved collaboratively to discuss, plan, observe each other's practice and, make suggestions for improvement. Identifying student needs, sharing their own language-focused principles and then channelling these into shared principles helped to establish a shared goal (to help the students write more effectively). The role of the shared goal is critical as it drives the planning and lifts it to a new level. A final linguistic product, such as writing descriptive sentences meant there was a tangible language outcome around which planning could be based. Furthermore, through this collaboration the planning process was made easier, and in particular, deciding on which tasks were most appropriate.

\section{Elements that enabled Mark and Dianne to learn from one another}

Various conditions or elements were evident that ensured the success of their collaboration. The teachers required a number of opportunities to learn and experience changes to their practice (Timperley, 2008). This requires a substantive period of time in order for change to take place (Garet et al., 2001; Lee \& Buxton, 2013; Timperley, 2008). The teachers in this study undertook the project over a relatively short time period, but they had a number of opportunities to try out their ideas both by discussing them together and then trialling them in their respective classrooms.

Another element of their collaboration was that both teachers were engaged in the process and willing to try new ideas through shared planning. In order to be able to accomplish this, it is important that teachers have the opportunity to experience learning in an environment that is trustful but also challenging (Timperley, 2008).

We also recognise that such collaborations do not occur in a vacuum. It requires support from external parties to build a spirit of collaboration and facilitate professional learning as teachers grapple with challenges that arise (Timperley, 2008). Meirink et al. (2010) suggest that leaders and coaches of voluntary teams encourage participants to experiment with new methods to ensure new learning. This support came from a number of areas. The action research project enabled the participant teachers to discuss their teaching challenges not only with each other but also with non-science teachers in the larger study, thus drawing on others' expertise. In doing so, there were multiple 
opportunities in which the teachers could be challenged and reflect on their own practice, conditions necessary for professional learning (Timperley, 2008). Moreover, the success of the collaboration through the facilitation of the action research project by the TESOL educator was also important.

Their collaboration with the TESOL educator was, however limited to a focus on TESOL, and so there may have been missed opportunities for the learning of science. The TESOL educator was able to support the teachers within the field of language learning but they did not have expertise in the teaching of science. While the teachers were experienced teachers of science it is possible that an expert science educator may have been able to assist the pair with respect to science pedagogical content knowledge (PCK) or epistemic knowledge of science. Bringing in a science educator to work alongside the TESOL educator and teachers could have provided a useful conduit between the teaching of science and the teaching of English language and led to an even richer development of teachers' science and language learning.

\section{How Dianne and Mark used these elements to bring about change}

The teachers in this study contributed to the creation of a trustful environment in which they could challenge each other's ideas. Mark and Dianne volunteered to be part of the action research project and set up their own dyad. They entered the partnership on the basis of trust having met each other previously, albeit briefly. While Timperley (2008) suggests that voluntary participation is not a requirement for engagement it appears from this study, by choosing their partner they recognised the benefit of working together with someone who worked in a similar context.

As well as being voluntarily part of a team they also volunteered to be part of the action research project as a whole. The act of volunteering supported an autonomous working environment. Often learning is considered to be an output of collaboration as an "organizational condition" (Meirink et al. 2010, p. 175). In this study, there was no coercion from their school leaders to participate in the project. This lack of pressure to be part of a team, coupled with the opportunity to act autonomously to set their goals supported their learning. Such relationships "are to be viewed as co-created by teachers as actors, instead of organizational conditions outside teachers' sphere of discretion" (p. 175).

Within language and literacy-based work, science teachers tend to focus on improving students' science content knowledge (Christenson, Gericke, \& Chang Rundgren, 2017). By working together as a team, Mark and Dianne were able to construct a plan that included tasks to increase not only students' science content knowledge but also to support their students to achieve the linguistic goal they had set. The shared planning was motivational and it was this plan which forced them not just to experiment, but rather to sustain experimentation with these alternative teaching methods. Having devised the plan and new methods they were able to share how the different activities played out in each other's classes. Same-subject collaboration gives the opportunity for detailed assistance in bringing a language focus to a particular topic. Giving and receiving such assistance is at the heart of teacher learning.

In sustaining this experimentation both teachers had to convince the students of the value of this approach but in the end were rewarded with a new level of student engagement. They realised that they did in fact use effective 
teaching approaches - just not consistently. Their engagement and willingness to try new ideas through their collaboration had enabled this to occur.

While the TESOL educator's leadership was important throughout the project, within the dyad Dianne took on a leadership role. While both teachers contributed to the design of useful resources for their shared plan, Dianne led the planning and design process of the interactive activities. In addition, she was able to show Mark new teaching approaches which he experimented with. So, while external support is important, leadership within the team was also crucial. It appears these different roles and personal goals had implications for their future collaboration, however.

While they were undertaking the project both teachers were engaged and achieved their shared goal, but they were unable to sustain an ongoing relationship after the project completion. By the end of their action research, Dianne had the confidence and competence to continue to develop a language focus by herself, whereas Mark still felt the need for external support. Questions for further research arose for us: How can ongoing support for temporary, voluntary teams be created? What is the lifespan of a temporary team, should they disband and reform with others? How can teachers be supported to be increasingly self-regulatory as an inquiry draws to a close?

\section{CONCLUSION}

Too often, teachers are required to make changes in classroom practice without having the knowledge base, time and guidance to work together. This article contributes a detailed example of teachers working together. Through revealing the nature of the collaboration, we have uncovered professional learning opportunities and conditions that contributed to a successful collaboration to achieve a shared goal.

Voluntary, temporary teams with the autonomy to decide on their own direction is a promising development in secondary school teacher learning. This article also points to the need for such teams to be resourced not just theoretically and practically, but also collegially. The teachers' experience in this study has shown that making changes involves risk taking and confidence and needs collegial support. While recognising the small number of participants in the collaboration, we posit that without the conditions of collaboration leading to change, expectations that teacher beliefs and practice will change in line with reform initiatives will founder.

Manuscript Submitted: August 8, 2019

Revised Manuscript Received: October 16, 2019

Revised Manuscript Accepted: November 5, 2019 


\section{REFERENCES}

Bryman, A. (2012). Social research methods. (4th ed.). New York, NY: Oxford University Press.

Christenson , N., Gericke, N., \& Chang Rundgren, S.-N. (2017). Science and language teachers' assessment of upper secondary students' socioscientific argumentation. International Journal of Science and Mathematics Education, 15(8), 1403-1422.

DiPardo, A., \& Potter, C. (2003). Beyond cognition. In A. Kozulin, B. Gindis, V. Ageyev, \& S. Miller (Eds.), Vygotsky's educational theory in cultural context (pp. 317-345). Cambridge, England: Cambridge University Press.

Elliot, J. (1991). Action research for educational change. Milton Keynes, England: Open University Press.

Garet, M., Porter, A., Desimone, L., Birman, B., \& Yoon, K. (2001). What makes professional development effective? Results from a national sample of teachers. American Educational Research Journal 38(4): 915-45. doi: $10.3102 / 00028312038004915$

Hargreaves, A. (2000). Four ages of professionalism and professional learning. Teachers and Teaching: History and Practice, 6(2), 151-182.

Higgins, E. (1996). The 'self-digest': Self-knowledge serving self-regulatory functions. Journal of Personality and Social Psychology, 71(6), 10621083.

Kaufman, D. \& Crandall, J. (2005). Standards- and content-based instruction: Transforming language education in primary and secondary schools. In D. Kaufman \& J. Crandall, (Eds.), Content-based instruction in primary and secondary school settings (pp. 1-11) Alexandria, VA: TESOL.

Kubanyiova, M. (2009). Possible selves in language teacher development. In Z. Dörnyei \& E. Ushioda (Eds.), Motivation, language identity and the L2 self (pp.314-332). Bristol, England: Multilingual Matters.

Lee, O., \& Buxton, C. (2013). Teacher professional development to improve science and literacy achievement of English Language Learners. Theory into Practice, 52(2), 110-117.

Levine, T., \& Marcus, A. (2010). How the structure and focus of teachers' collaborative activities facilitate and constrain teacher learning. Teaching and Teacher Education, 26(3), 389-398.

Loughland, T., \& Nguyen, H. (2016). Using the instructional core to implement a professional learning programme for primary science teachers in Australia: Teacher learning and student skill outcomes. Teacher Development 20(4), 498-520.

Meirink, J., Imants, J., Meijer, P., \& Verloop, N. (2010). Teacher learning and collaboration in innovative teams. Cambridge Journal of Education, 40(2), 161-181.

Miles, M. B., \& Huberman, A. M. (1994). Qualitative data analysis. (2 ${ }^{\text {nd }}$ ed.). Thousand Oaks, CA: Sage.

Ministry of Education. (2007). The New Zealand curriculum for English-medium teaching and learning in years 1-13. Wellington, New Zealand: Learning Media. 
Timperley, H. (2008). Teacher professional learning and development. Retrieved from

http://www.ibe.unesco.org/fileadmin/user upload/Publications/Education al Practices/EdPractices 18.pdf

Wylie, C. (2010). Focusing leadership on adult learning: The secondary school challenge. Journal of Educational Leadership, Policy and Practice, 25(1), 51-66. 


\section{ABOUT THE AUTHOR(S)}

\section{SUSAN GRAY}

The University of Auckland

Auckland, New Zealand

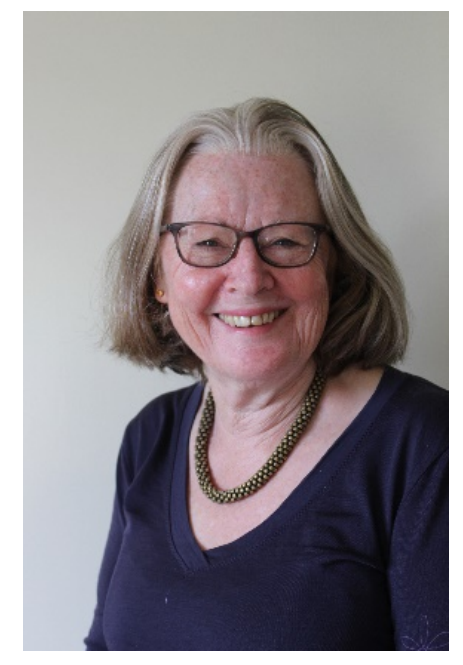

Susan Gray has had over 20 years of experience as a TESOL educator in the Faculty of Education and Social Work at the University of Auckland. Her previous experience includes primary and secondary school teaching. Her research in the area of TESOL education has been published both nationally and internationally.

\section{GILLIAN WARD}

The University of Auckland

Auckland, New Zealand

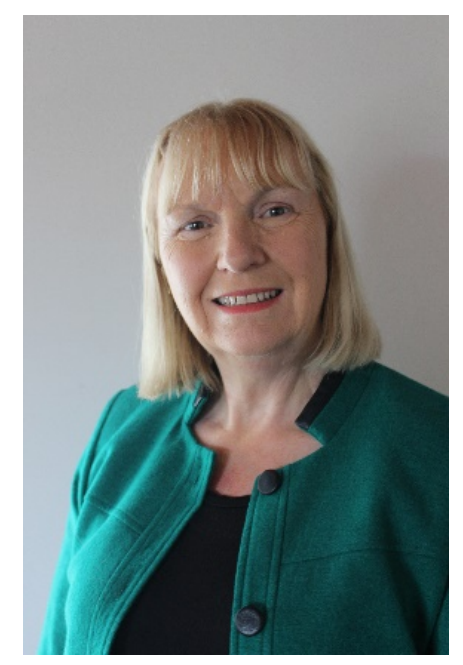

Gillian Ward is a science educator in the Faculty of Education and Social Work at the University of Auckland. She teaches science education in initial teacher education programmes and postgraduate programmes. Her research interests focus on teacher professional learning in the areas of science education and higher education. She has published both nationally and internationally.

\footnotetext{
The opinions expressed are those of the paper author(s) and not the New Zealand Journal of Teachers' Work. Copyright is held by individual authors but offprints in the published format only may be distributed freely by individuals provided that the source is fully acknowledged. [ISSN-1176-6662]
} 